REFLEKSI HUKUM

Jurnal Ilmu Hukum
p-ISSN 2541-4984 | e-ISSN 2541-5417

Volume 2 Nomor 2, April 2018, Halaman 109 - 124

DOI: https://doi.org/10.24246/jrh.2018.v2.i2.p109-124

Open access at: http://ejournal.uksw.edu/refleksihukum Penerbit: Fakultas Hukum Universitas Kristen Satya Wacana

\title{
KEMAJEMUKAN VISI NEGARA HUKUM PANCASILA DALAM MISI HUKUM NEGARA INDONESIA
}

\author{
Sarip \\ Departemen Hukum Tata Negara \\ Fakultas Hukum Universitas Muhammadiyah Cirebon \\ Korespodensi: sarip_anisa@yahoo.co.id \\ Abdul Wahid \\ Departemen Hukum Keperdataan \\ Fakultas Hukum Universitas Muhammadiyah Cirebon
}

\begin{abstract}
Abstrak
Kemajemukan bangsa Indonesia sebagai satu kesatuan yang tidak terpisahkan. Kemajemukan merupakan hasil catatan sejarah negara hukum Indonesia. Negara hukum Indonesia yang bertumpu pada Pancasila sebagai falsafah negara bangsa merupakan visi negara. Teori negara hukum Arsitoteles walaupun sederhana, sampai perkembangan konsepsi negara hukum Pancasila merupakan sarana yang dapat digunakan untuk menjawab permasalahan negara hukum dalam hukum negara itu sendiri. Hasilnya negara hukum dapat dikatakan sebagai visi negara Indonesia sedangkan hukum negara dapat dikatakan sebagai misi yang digunakan untuk mencapai visi negara hukum Pancasila. Visi negara hukum mesti diurai dengan hukum negara harus melibatkan nilai-nilai Pancasila dalam menggapai negara hukum Pancasila.
\end{abstract}

Kata Kunci: Kemajemukan, Negara Hukum, Hukum Negara, Pancasila.

\begin{abstract}
The plurality of the Indonesian nation is an integral whole. Pluralism is the result of historical records of the Indonesian law-based state. It is a vision of the State to rely on Pancasila as the State's philosophy. A simple theory of law-based state pioneered by Aristotle and the development of a concept of the Pancasila law-based state are means that can be used to resolve problems regarding law-based state issues in the laws of the state. As a conclusion, the concept of a lawbased state could be considered as the Indonesian vision, while the state laws could be considered as a mission to achieve the Pancasila law-based state's vision. The vision of law-based state should be enforced by the state laws which implement Pancasila to form a Pancasila lawbased state.
\end{abstract}

Keywords: Pluralism, State Law, Legal State, Pancasila. 


\section{PENDAHULUAN}

Kemajemukan bangsa Indonesia telah ada jauh sebelum Indonesia sebagai nation state (negara bangsa) modern. ${ }^{1}$ Negara bangsa modern merupakan klaim yang tidak terbantahkan berkenaan dengan kemajemukan, warisan luhur sebagai negara bangsa. ${ }^{2}$ Kemajemukan ditunjukan dengan adanya berbagai suku-suku bangsa atau yang sering dikenal sebagai masyarakat dalam syarat berdirinya negara. Terbentuknya Negara Kesatuan Republik Indonesia (NKRI) tanggal 17 Agustus 1945, didasarkan pada teori negara hukum dan negara bangsa. ${ }^{3}$ Proklamasi, Pancasila, dan UUD 1945 sebagai perekat negara bangsa Indonesia yang majemuk. ${ }^{4}$ Penelusuran negara hukum sendiri sudah sejak jaman filosof Yunani yakni Plato dan Aristoteles, negara hukum yang ideal memadukan antara polis (negara) dan perundangundangan, dikenal sebagai negara polis. ${ }^{5}$

Kemajemukan negara bangsa dipahami sebagai perbedaan yang disatukan dalam hukum positif (hukum negara). Kemajemukan suku bangsa Indonesia diumumkan melalui Proklamasi (iklar negara bangsa), diikat falsafah Pancasila (groundnorm), dan direalisasikan dalam UUD 1945 (staatsfundamentalnorm). Kemudian dijadikan visi negara hukum Pancasila yang memuat nilai: ketuhanan, kemanusiaan, persatuan, kerakyatan, dan nilai keadilan. ${ }^{6}$ Kemajemukan diikat kembali oleh misi hukum negara Indonesia yang lebih dikenal sebagai hukum positif Indonesia. ${ }^{7}$ Persoalan yang kemudian mengemuka yaitu

1 Cornelis Lay, 'Nasionalisme dan Negara Bangsa' (2006) 10 Jurnal Ilmu Sosial dan Ilmu Politik 159, 165-180. Sugiyarto, 'Tantangan Terhadap Eksistensi Negara Bangsa Indonesia dalam Pemaknaan Kembali Nasionalisme', http://eprints.undip.ac.id/57965/1/Tantangan_terhadap_Eksistensi_Negara_Bangsa_Indonesia_da n_Pemaknaan_Kembali_Nasionalisme.pdf akses 20 Februari 2018. Muhammad Mutaqim dan Muhammad Miftah, 'Tantangan Negara-Bangsa (Nation-State) dalam Menghadapi Fundamentalisme Islam' (2015) 9 Jurnal ADDIN 77, 85-106. Kata kemajemukan berasal dari kata majemuk yang berarti terdiri dari beberapa bagian yang merupakan satu kesatuan, https://www.kbbi.web.id/majemuk. Akses 2 Februari 2018.

2 Manneke Budiman, 'Jatidiri Budaya Dalam Masyarakat Multikultural' Makalah Seminar Pendidikan Multikultural dan Revitalisasi Hukum Adat dalam Perspektif Budaya, Departemen Kebudayaan dan Pariwisata, Bogor 18-20 Desember 2003.

3 Lihat UUD 1945 BAB I tentang Bentuk dan Kedaulatan Pasal 1 Ayat (1) dan (3) Amandemen Ketiga. Lihat juga Pancasila dari Sila Pertama sampai Sila Lima.

$4 \quad$ Moh.Mahfud MD, Konstitusi dan Hukum dalam Kontroversi Isu (PT Rajagrafindo Persada 2009) 34-39. Moh. Mahfud MD, dalam Adrianus M. Ngoro, 'Makna Negara Hukum dalam Persefektif Politik Hukum: Telaah Yuridis Materil dan Formil' (2017) 2 Jurnal Hukum Sehasen 16, 20-66.

5 Dahlan Taib dalam Sayuti, 'Konsep Rechtsstaat dalam Negara Hukum Indonesia: Kajian Terhadap Pendapat Azhari' (2017) 4 Jurnal Kajian Islam dan Kemasyarakatan NALAR FIQH 70, 81. Herman Bakir dalam Hayat, 'Keadilan Sebagai Prinsip Negara Hukum: Tinjuan Teoritis dalam Konsep Demokrasi' (2015) 2 Jurnal Ilmu Hukum PADJAJARAN 385, 391.

6 Bandingkan Safroedin Bahar dkk. Peny, Risalah Sidang Badan Penyelidik Usaha-Usaha Persiapan Kemerdekaan Indonesia (BPUPKI)-Panitia Persiapan Kemerdekaan Indonesia (PPKI): 28 Mei 1945 - 22 Agustus 1945 (Sekretariat Negara Republik Indonesia Jakarta 1995) 419. Lihat Irfan Nasution dan Roni Agustinus (Peny.), Restorasi Pancasila; Mendamaikan Politik Identitas dan Modernitas, (FISIP UI 2006) 100.

7 Sigit Riyanto, Re-interprestasi Kedaulatan Negara dalam Hukum Internasional, dalam Pidato Pengukuhan Jabatan Guru Besar Fakultas Hukum Universitas Gajah Mada Yogyakarta, tanggal 26 Juni 2014, 3. 
landasan-landasan apakah yang mendasari visi negara hukum yang dapat menjadikan kemajemukan sebagai misi dalam hukum negara Pancasila.

Tulisan ini menggunakan pendekatan hukum normatif yang mana dilakukan dengan mengkaji, menganalisis, dan memikirkan kembali tentang negara hukum terutama ketentuan hukum yang berkaitan dengan masalah penulisan. Analisis dilakukan dengan cara deskriptif kualitatif, yakni menguraikan dalam bentuk kalimat yang tersusun secara sistematis, lengkap, dan berdasarkan pokok bahasan sehingga mempermudah dalam pengambilan kesimpulan.

\section{PEMBAHASAN}

\section{Teori Negara Hukum (Visi) dan Model Pemikiran Hukum Negara (Misi)}

Negara hukum merupakan istilah yang meskipun kelihatan sederhana, namun mengandung muatan sejarah pemikiran yang relatif panjang. ${ }^{8}$ Pemikiran negara hukum telah muncul jauh sebelum Revolusi 1688 (Inggris), muncul kembali pada abad XVII dan populer pada abad XIX. ${ }^{9}$ Timbulnya pemikiran negara hukum, merupakan reaksi terhadap kesewenanganwenangan di masa lampau. ${ }^{10}$ Unsurunsur negara hukum mempunyai hubungan erat dengan sejarah, perkembangan masyarakat, dan negara bangsa.

Sejarah pemikiran negara hukum sebenarnya sudah tua, jauh lebih tua dari pengetahuan negara atau kenegaraan. Pemikiran negara hukum dimulai sejak Plato dengan konsepnya "bahwa penyelenggaraan negara yang baik adalah berdasarkan peraturan (hukum) yang baik yang disebut dengan istilah nomoi". 11 Pernyataan Plato yang menyatakan "...berdasarkan peraturan (hukum)... istilah nomoi" pada dasarnya merupakan hukum negara atau hukum positif atau misi. Justru pernyataan negara hukum sendiri terlihat dari kalimat "Penyelenggaraan negara yang baik..." yang merupakan visi negara.

Gagasan negara hukum yang telah dikemukan Plato merupakan konsep nomoi yang dibuat pada masa tuanya. Sementara itu dalam tulisan pertama Politeia dan Politicos, belum muncul negara hukum. Negara hukum kemudian dipertegas oleh Aristoteles yang menuliskan Politica. ${ }^{12}$ Pengertian negara hukum Aristoteles dikaitkan dengan arti daripada dalam perumusannya yang masih terikat pada "polis". Pengertian negara hukum Aristoteles timbul dari "polis" yang memiliki wilayah negara kecil, seperti kota, berpenduduk sedikit, dan tidak seperti negara-negara sekarang yang mempunyai wilayah luas dan penduduk banyak (vlakte staat).

$8 \quad$ Majda El. Muhtaj, Hak Asasi Manusia dalam Konstitusi Indonesia (Kencana 2005) 1.

9 Phlipus M. Hadjon, Kedaulatan Rakyat Negara Hukum dan Hak Asasi Manusia: Kumpulan Tulisan dalam Rangka 70 Tahun Sri Soemantri Mertosoewignjo (Media Pratama 1996) 72.

10 Phlipus M. Hadjon, Perlindungan Hukum Bagi Masyarakat di Indonesia (Bina Ilmu 1987) 72.

11 Ni'matul Huda, Negara Hukum Demokrasi dan Judicial Review (UII Press 2005) 1. Lihat Titik Triwulan Tutik, Pokok-Pokok Hukum Tata Negara, (Prestasi Indonesia 2006) 65.

12 Ridwan HR, Hukum Administrasi Negara (PT. Raja Grafindo Persada 2006) 2. Lihat Sarip, Hukum Tata Negara Materil (Elsi Pro 2018) 32-34. 
Negara polis, segala urusan negara dilakukan dengan musyawarah (ecclesia), dimana seluruh warga negara ikut serta dalam urusan penyelenggaraan negara. ${ }^{13}$ Pada masa "polis" yang dimaksud dengan negara hukum ialah negara yang berdiri di atas hukum yang menjamin keadilan kepada warga negaranya. Sebab, keadilan merupakan syarat bagi tercapainya kebahagian hidup untu warga negara dan sebagai dasar keadilan itu perlu ajaran rasa susila kepada setiap manusia agar menjadi warga negara yang baik. ${ }^{14}$ Peraturan hukum sebenarnya hanya ada jika peraturan hukum itu mencerminkan keadilan bagi pergaulan hidup antar warga negara. ${ }^{15}$

Bagi Aristoteles negara hukum memiliki visi terhadap pendidikan susila, sedangkan misi hukum negara terdapat pada pembentukan peraturan hukum tidak berlebihan. Sebab yang memerintah dalam negara bukanlah manusia yang sebenarnya melainkan pikiran yang adil, sedangkan kekuasaan yang sebenarnya hanya memegang hukum dan keseimbangan saja. ${ }^{16}$

Kesusilaan sebagai visi negara hukum menentukan baik dan tidaknya suatu peraturan perundang-undangan dan membuat undang-undang adalah sebagian dari kecakapan menjalankan pemerintahan negara. ${ }^{17}$ Menurutnya yang penting adalah mendidik manusia untuk menjadi warga negara yang baik, karena sikap negara yang adil akan menjamin kebahagian hidup warga negara. ${ }^{18}$ Ajarannya sampai sekarang masih menjadi idaman bagi para negarawan untuk mencapai visi negara hukum yang berkeadilan. ${ }^{19}$

Misi hukum negara Aristoteles juga menyatakan bahwa suatu negara yang baik adalah negara yang diperintahkan dengan konstitusi ${ }^{20}$ dan berkedaulatan hukum. ${ }^{21}$ Ada tiga unsur dari pemerintahan yang berkonstitusi, yaitu:22

a. Pemerintahan dilaksanakan untuk kepentingan umum;

b. Pemerintahan dilaksanakan menurut hukum yang berdasarkan ketentuan umum, bukan hukum yang dibuat sewenang-wenang menyampingkan konvensi ${ }^{23}$ dan konstitusi; dan

c. Pemerintah berkonstitusi berarti pemerintahan yang dilaksanakan atas kehendak rakyat, bukan berupa paksaan, tekanan yang dilaksanakan pemerintahan despotik.

13 Moh. Kusnardi dan Harmaily Ibrahim, Hukum Tata Negara Indonesia (Sinar Bakti 1987$) 153$.

14 Rozikin Daman, Hukum Tata Negara (PT. Raja Grafindo Persada 1993) 166.

15 Moh. Kusnardi dan Harmaily Ibrahim, Op.Cit 153.

16 Rozikin Daman, Op.Cit 166.

17 Moh. Kusnardi dan Harmaily Ibrahim, Op.Cit 154.

18 Rozikin Daman, Op.Cit 167.

19 Moh. Kusnardi dan Harmaily Ibrahim, Op.Cit 154.

20 Tahir Azhary, Negara Hukum Indonesia (UI Press 1995)20-21.

21 Dahlan Thaib, Kedaulatan Rakyat Negara Hukum dan Hak Asasi Manusia: Kumpulan Tulisan dalam Rangka 70 Tahun Sri Soemantri Mertosoewignjo (Media Pratama 1996) 22.

22 Ridwan HR, Op.Cit 2.

23 Konvensi adalah permufakatan atau kesepakatan (terutama mengenai adat, tradisi, dan sebagainya), sedangkan sespotik adalah penguasa tunggal yang berbuat sekehendak hati; kepala negara atau raja yang menjalankan kekuasaan dengan sewenang-wenang, https://www.kbbi.web.id/konvensi, akses 20 Februari 2018. 
Fakta menunjukkan bahwa masyarakat Indonesia tidak dapat memenuhi keinginan dan kebutuhannya yang begitu banyak dan yang begitu beraneka-ragam dengan kemampuan dan keterampilannya sendiri. Tetapi mereka saling membutuhkan satu dengan lainnya demi kepentingan masing-masing. Kemudian mereka lalu sepakat untuk bekerja sama sesuai bakat, kemampuan, dan keterampilan masingmasing di suatu tempat yang dialami bersama dan selanjutnya lahirlah apa yang disebut negara bangsa. ${ }^{24}$

Visi negara hukum tercapai apabila ketiga misi hukum negara dapat berfungsi sebagaimana mestinya: yaitu jika pembagian kerja diatur sesuai dengan bakat, bidang keahlian dan keterampilan setiap warga negara. Jadi apabila semua orang dan semua kelas dalam negara dapat berfungsi sebagaimana mestinya dan kebutuhan serta keinginan manusia yang banyak dan beraneka-ragam benar-benar terpuaskan, negara makmur, dan keutuhan terpelihara dengan baik, maka dapat dikatakan bahwa ada keadilan dalam negara itu. 25

Dalam perkembangannya negara hukum dapat dilihat dari berbagai model yang berkenaan dengan negara hukum, setidaknya ada lima model negara hukum, yakni:

1. Negara hukum menurut nomokrasi Islam;26

2. Negara hukum menurut Eropa Kontinental (rechtsstaat);27

3. Negara hukum menurut Anglo Saxon (rule of law);28

4. Negara hukum menurut socialist legality; 29 dan

5. Negara hukum Pancasila di Indonesia. 30

Negara hukum sebagaimana dipahami sebagai tindakan negara berdasarkan pada hukum, sebagaimana disebutkan Aristoteles. Apabila perkataan negara hukum dibalik maka akan menjadi hukum negara, hal ini yang kiranya belum banyak diketahui oleh berbagai kalangan. Negara hukum dalam lima model tersebut,

24 Nurdin, 'Konsep Kedaulatan dan Keadilan dalam Konsep Islam dan Barat' (2011) XIII Jurnal Media Syariah 123,126.

25 Rapar dalam Nurdin, Ibid 127.

26 Suatu negara yang memiliki prinsip-prinsip kekuasaan sebagai amanah, musyawarah, keadilan persamaan, pengakuan dan perlindungan hak asasi manusia, peradilan bebas, perdamaian, kesejahteraan, dan ketaatan rakyat. Tahir Azhary, Negara Hukum, (Kencana 2010) 85-86.

27 Negara hukum yang menentang absolutism sehingga sifatnya revolusioner, bertumpu pada civil law dengan karakter administratif. Lihat Ridwan HR, Op.Cit 1. Philipus M. Hadjon, Op.Cit 72. Ni'matul Huda, Hukum Tata Negara Indonesia, (PT. Raja Grafindo Persada 2006) 74. AV. Dicey dalam Wahyu Djafar, 'Menegaskan Kembali Komitmen Negara Hukum: Sebuah Catatan Atas Kecenderungan Defisit Negara Hukum di Indonesia' (2010) 7 Jurnal Konstitusi, 143, 153. Lihat Jimly Ashiddiqie, Konstitusi dan Konstitusionalisme Indonesia, (Konstitusi Press 2005) 52.

28 Memiliki sifat revolusioner bertumpu pada common law adalah yudicial. Lihat Ridwan HR, Op.Cit 1. Philipus M. Hadjon, Op.Cit 72. Ni'matul Huda, Op.Cit 74.

29 Merupakan negara hukum yang diterapkan dalan negara sosialis dalam rangka mengimbangi rechtsstaat dan rule of law. Lihat Tahir Azhari, Op.Cit 91.

30 Ridwan HR, Op.Cit 2. Negara hukum Indonesia atas keinginan bangsa Indonesia untuk membina kehidupan negara dan masyarakat yang lebih baik guna mencapai tujuan yang telah ditetapkan, menurut cara-cara yang telah disepakati, Bambang Arumanadi dan Sunarto, Konsepsi Negara Hukum Menurut UUD 1945, (IKIP Semarang Press 1990) 106. Bandingkan Satjipto Rahardjo, Negara Hukum yang Membahagiakan Rakyatnya (Genta Publishing 2009) vii. 
menandakan akan cita-cita negara yang berdasarkan hukum itu sendiri atau sering dikenal dengan visi negara hukum. Hukum negara dapat dikatakan sebagai misi negara dalam mencapai visi tersebut. 31 Hal ini sejalan dengan pandangan Aristoteles tentang keadilan yang menitik-beratkan pada misi dalam negara, yakni:

a. Keadilan distributif yaitu suatu keadilan yang ditentukan oleh pembuat undang-undang, yang distribusinya memuat jasa, hak dan kebaikan bagi anggota-anggota masyarakat menurut prinsip kesamaan proporsional. Keadilan dalam hal ini harus memiliki standar dan ukuran yang jelas serta ditegakkan secara transparan.

b. Keadilan korektif yaitu suatu keadilan yang pada prinsipnya diatur oleh hakim yang menjamin, mengawasi dan memelihara distribusi ini dari seranganserangan illegal. Fungsi korektif keadilan ini juga menciptakan status quo dengan cara mengembalikan milik korban yang bersangkutan atau dengan cara mengganti rugi hak yang hilang kepada pemiliknya. ${ }^{32}$

Dalam konteks Indonesia yang memiliki visi negara hukum, mutlak diperlukan misi hukum negara atau keduanya tidak dapat dipisahkan. Apabila hanya negara hukum saja yang diutamakan maka dapat dikatakan bahwa Indonesia merupakan negara yang sedang bermimpi di siang hari. Begitu juga apabila hanya misi hukum negara saja yang diutamakan, akan menunjukkan bahwa negara Indonesia bekerja tanpa tujuan yang jelas atau tidak memiliki arah. Mewujudkan negara hukum melalui hukum negara secara otomatis diperlukan adanya kedaulatan negara. ${ }^{33}$ Kedaulatan negara dalam bentuk hukum negara, merupakan sarana yang efektif dalam mewujudkan negara hukum sebagaimana yang diharapkan yakni negara hukum Pancasila.

Jimly Ashiddiqie, dengan mendasarkan pada beragam pemikiran tentang negara hukum, menyebutkan setidaknya terdapat tiga belas prinsip pokok yang harus dimiliki negara hukum (rechtsstaat), yaitu: ${ }^{34}$

1. Supremasi hukum (supremacy of law);

2. Persamaan dalam hukum (equality before the law);

3. Asas legalitas (due process of law);

4. Pembatasan kekuasaan;

5. Organ-organ eksekutif independen (executive auxiliary agencies);

31 Tidak ada keadilan yang sempurna di dunia ini. Lihat Nurdin, Op.Cit 122.

32 Muhammad Muslehuddin, Filsafat Hukum Islam dan Pemikiran Orientalis, terj. Yudian Wahyudi Asmin, (Tiara Wacana 1991) 36.

33 Kedaulatan (Bahasa Indonesia), sovereign (Inggris), dan dalam bahasa Latin disebut supernuus (Supreme) bermakna tertinggi atau kekuatan tertinggi. Kata ini dipergunakan dalam ilmu politik modern, untuk menunjukkan pengertian otoritas mutlak. Muhammad Muslehuddin, Ibid 45. Menurut teori kedaulatan hukum (Rechts-souvereiniteit) yang memiliki bahkan yang merupakan kekuasaan tertinggi di dalam suatu negara itu adalah hukum itu sendiri. Karena baik raja atau penguasa maupun rakyat bahkan negara itu sendiri tunduk kepada hukum. Suhieno, Imu Negara, (Liberty 1986), 152-153. Bandingkan dengan Jenik Radon dalam Sigit Riyanto, 'Kedaulatan Negara dalam Kerangka Hukum Internasional Kontemporer' (2012) 1 Jurnal Yustisia 1,6.

34 Bandingkan Jimly Ashiddiqie, Pokok-Pokok Hukum Tata Negara Pasca Reformasi (Buana Ilmu Populer 2007) 310. 
6. Peradilan yang bebas dan tidak memihak;

7. Peradilan tata usaha negara (administrative court);

8. Peradilan tata negara (constitutional court);

9. Perlindungan hak asasi manusia;

10. Bersifat demokratis;

11. Berfungsi sebagai sarana mewujudkan tujuan bernegara;

12. Transparansi dan kontrol sosial.

13. Ber-Ketuhanan Yang Maha Esa, selain itu pada prinsip taransparansi dan kontrol sosial, menambahkan adanya prinsisp pers yang bebas dan prinsip akuntabilitas. ${ }^{35}$

Apa yang dikatakan Jimly Ashiddiqie dapat juga dikatakan sebagai misi dari negara hukum itu sendiri. Point 13 sendiri merupakan misi hukum negara yang berbeda pada umumnya. Hal ini mengindikasikan bahwa Jimly Ashiddiqie menaruh perhatian khusus terhadap negara hukum Pancasila yang ada di Indonesia. ${ }^{36}$ Acuan pandangan Jimly Ashiddiqie yaitu pada pembukaan UUD 1945, sebagai berikut:

"Perjuangan pergerakan kemerdekaan Indonesia telah sampailah kepada saat yang berbahagia dengan selamat sentausa mengantarkan rakyat Indonesia kedepan pintu gerbang kemerdekaan Negara Indonesia, yang merdeka, bersatu, berdaulat, adil dan makmur. Atas berkat rakhmat Allah Yang Maha Kuasa dan dengan di dorongkan oleh keinginan luhur, supaya berkehidupan kebangsaan yang bebas, maka rakyat Indonesia menyatakan dengan dengan ini kemerdekaannya."37

Hal senada ditegaskan oleh Satjipto Rahardjo bahwa bangsa yang merdeka sudah sepantasnya mempunyai dan membangun teori hukum sendiri, teori hukum Indonesia.38 Suatu hal yang diakui sendiri oleh Satjipto Rahardjo sebagai bukan pekerjaan sederhana, lebih lagi sebagai negara post-kolonial yang mengalami masa panjang pengalaman kolonialisme. ${ }^{39}$ Kendati secara implisit proklamasi kemerdekaan memiliki makna politis dan yuridis sebagai pernyataan lepas dari ikatan kekuasaan kolonial dan melahirkan kedaulatan bagi bangsa Indonesia untuk mengganti hukum colonial menjadi hukum nasional.

\section{Hukum Negara Mengemban Lima Sila Pancasila}

Kemajemukan hukum Indonesia
pada dasarnya dapat dilihat dari
Pancasila yang merupakan falsafah

35 Lihat Pancasila terutama Sila Pertama.

36 Bandingkan Made Hendra Wijaya, 'Karakteristik Konsep Negara Hukum Pancasila' (2015) 5 Jurnal Advokasi 187, 199-214. Pasal 1 ayat (3) UUD 1945 menyebutkan bahwa "Negara Indonesia adalah negara hukum" Negara hukum dimaksud adalah negara yang menegakkan supremasi hukum untuk menegakkan kebenaran dan keadilandan tidak ada kekuasaan yang tidak dipertanggungjawabkan, Majelis Permusyawaratan Rakyat Republik Indonesia, Panduan Pemasyarakatan Undang-Undang Dasar Republik Indonesia Tahun 1945 (Sesuai dengan Urutan Bab, Pasal, dan ayat) (Sekretaris Jendral MPR RI Jakarta 2010) 46.

37 Pembukaan UUD 1945 Alinea 2 dan 3.

38 Satjipto Rahardjo, Pendidikan Hukum Sebagai Pendidikan Manusia (Genta Publishing, 2009) 118.

39 Lihat Aidul Fitriciada Azhari, Negara Hukum Indonesia: Dekolonisasi dan Rekonstruksi Tradisi' (2012) 19 Jurnal Hukum Ius Quia Iustum 491,497. 
bangsa Indonesia. ${ }^{40}$ Secara yuridis dan historis kemajemukan negara hukum Pancasila sebagaimana termuat dalam Pembukaan UUD 1945:

"Kemudian daripada itu untuk membentuk suatu pemerintahan negara Indonesia yang melindungi segenap bangsa Indonesia dan tumpah darah Indonesia dan untuk memajukan kesejahteraan umum, mencerdaskan kehidupan bangsa, dan ikut melaksanakan ketertiban dunia yang berdasarkan kemerdekaan Kebangsaan Indonesia itu dalam suatu UndangUndang Dasar Negara Indonesia, yang terbentuk dalam suatu susunan negara republik Indonesia yang berkedaulatan rakyat dengan berdasarkan kepada: Ketuhanan Yang Maha Esa, Kemanusiaan yang adil dan beradap; Persatuan Indonesia, Kerakyatan Yang Dipimpin Oleh Hikmat Kebijaksanaan Dalam Permusyawaratan/ Perwakilan, serta dengan mewujudkan suatu Keadilan Sosial Bagi Seluruh Rakyat Indonesia."41

Pancasila dapat dikatakan memiliki fungsi sebagai dasar falsafah negara atau Philosophische Grondslag, Wetanschauung, Ideologi Negara, Staatsfundamentalnorm, Staatsidee, cita hukum (rechtsidee) dari bangsa Indonesia. Sejalan dengan pendapat Khudzaifah Dimyati mengatakan: ${ }^{42}$

"Teorisasi dalam konteks membangun hukum yang bermuara pada konteks ke-Indonesia-an menjadi lebih penting, ketika pemikir hukum di negeri ini memiliki komitmen bahwa hukum nasional yang hendak diciptakan merupakan kerangka acuan bagi kehidupan berbangsa dan bernegara, untuk menemukan identitas hukum nasional.”

Pancasila sendiri berisikan tentang asas ketuhanan yaitu Ketuhanan Yang Maha Esa; asas kemanusiaan yaitu Kemanusiaan yang adil dan beradab, asas kebangsaan yaitu Persatuan Indonesia, asas kerakyatan yang diwujudkan dalam kedaulatan rakyat dengan bentuk demokrasi mufakat yaitu Kerakyatan yang dipimpin oleh hikmat kebijaksanaan dalam permusyawaratan/ perwakilan; serta asas keadilan sosial untuk kepentingan umum yaitu Keadilan sosial bagi seluruh rakyat Indonesia.

Negara hukum yang diharapkan diterapkan adalah negara hukum Pancasila, yaitu negara hukum yang berdasarkan atas kelima sila dari Pancasila yaitu:

1. Ketuhanan Yang Maha Esa ;

2. Kemanusiaan Yang Adil Dan Beradab ;

3. Persatuan Indonesia ;

4. Kerakyatan Yang Dipimpin Oleh Hikmat Kebijaksanaan Dalam Permusyawaratan/ Perwakilan ;

5. Keadilan Sosial Bagi Seluruh Rakyat Indonesia.

Kemajemukan bangsa Indonesia dalam bidang keagamaan merupakan suatu fakta keagamaan yang tidak terbantahkan. Maka sangat ideal nilainilai ketuhanan ditempatkan pada

40 Muhammad Tahir Azhary, Negara Hukum Suatu Studi tentang Prinsip-prinsipnya Dilihat dari Segi Hukum Islam Implementasinya pada Periode Negara Madinah dan Masa Kini (Predana Media 2003) 9798. Tengku Erwinsyahbana, 'Sistem Hukum Perkawinan pada Negara Hukum Berdasarkan Pancasila' (2012), 2 Jurnal Ilmu Hukum, 163, 173.

41 Lihat Pembukaan UUD 1945 dan Pancasila yang merupakan falsafah bangsa Indonesia sila pertama sampai sila lima.

42 Khudzaifah Dimyati dalam Dayanto, 'Rekontruksi Paradigma Pembangunan Negara Hukum Indonesia Berbasis Pancasila' (2013) 13 Jurnal Media Hukum 481,499. 
bagian awal dalam Pancasila. ${ }^{43}$ Sila Ketuhanan Yang Maha Esa memiliki inti kata Tuhan, secara morfologis mengandung makna abstrak atau suatu hal yaitu kesesuaian dengan hakikat nilai-nilai yang berasal dari Tuhan dan realisasinya adalah berupa nilai-nilai agama. ${ }^{44}$ Konsekuensinya pelaksanaan hukum negara Pancasila diukur sesuai nilai ketuhanan, dalam memberikan penjabaran lebih lanjut hukum negara yang mengatur manusia harus sesuai dengan nilai ketuhanan. 45

Aplikasinya hukum negara harus menjadi inti dari negara hukum haruslah terdapat nilai ketuhanan, nilai ketuhanan janganlah dipandang sempit hanya berpatokan pada suatu agama tertentu saja dan pertimbangan akan kemajemukan keagamaan yang ada otomatis harga yang tidak bisa ditawar. Sejalan dengan pernyataan Yusuf Muhammad yang menyatakan: 46

"...Ada sebuah teori yang mengatakan bahwa Konstitusi itu sebetulnya dibentuk, diperlukan untuk membatasi negara dari melakukan hal-hal yang tidak semestinya. Membatasi dari halhal yang tidak boleh dilakukan oleh negara karena menyangkut wilayah kebebasan warganya. Tetapi di sisi lain, kita juga melihat bahwa ada kewajiban bagi negara untuk memberikan pengayoman, perlindungan untuk memenuhi kebutuhan untuk mengakomodasi kepentingankepentingan mereka."

"Dua hal ini saya kira harus dapat kita jadikan titik tolak di dalam meletakkan hubungan antara negara dan agama. Satu hal yang pasti bahwa bagi kita hubungan negara dan agama masih sangat relevan, baik oleh karena kita melihat ada historis yang tidak mungkin kita lupakan, alinea di dalam Pembukaan yang mengatakan atas berkat rahmat Allah Yang Maha Kuasa, sesungguhnya merupakan landasan spiritual dari kelahiran negeri ini”.

"Di samping hal-hal yang seperti itu, kita juga melihat bahwa agama diperlukan untuk mendorong manusiamanusia, terbentuknya manusiamanusia pilihan bagi kepentingan kehidupan kita berbangsa dan bernegara. Di samping itu kita harapkan agama bisa menciptakan sebuah kebersamaan di antara pemeluk-pemeluk agama, dan ini kita akan bertemu dengan hal-hal yang universal di dalam tataran etika dan moral".

Ketuhanan Yang Maha Esa adalah Ketuhanan Yang Maha Satu, walaupun di dunia ini banyak terdapat agama, kepercayaan dan keyakinan, namun Tuhan itu satu, yang sangat agung dan baik, yang tidak pernah membedakan manusia satu dengan manusia

43 Mahkamah Konstitusi Republik Indonesia, Naskah Komprehensif Perubahan Undang-Undang Dasar Negara Republik Indonesia Tahun 1945:Latarbelakang, Proses dan Hasil Pembahasan 1999-2002 Buku VIII Warga Negara dan Penduduk, Hak Asasi Manusia dan Agama, Edisi Revisi, (Sekretariat Jenderal dan Kepaniteraan Mahkamah Konstitusi, 2010) 85.

44 Bandingkan dengan Made Hendra Widjaya, Op.Cit 206.

45 Nilai-nilai ketuhanan (religiositas) sebagai sumber etika dan spiritualitas (yang bersifat vertikaltransendental) dianggap penting sebagai fundamen etik kehidupan bernegara. Indonesia bukanlah negara sekuler yang ekstrem, yang memisahkan "agama" dan "negara" dan berpretensi untuk menyudutkan peran agama ke ruang privat/komunitas. Negara menurut alam Pancasila diharapkan dapat melindungi dan mengembangkan kehidupan beragama, sementara agama diharapkan dapat memainkan peran publik yang berkaitan dengan penguatan etika sosial, tetapi saat sama, Indonesia juga bukan "negara agama", yang hanya merepesentasikan salah satu (unsur) agama dan memungkinkan agama untuk mendikte negara. Yudi Latif, Negara Paripurna: Historisitas, Rasionalitas, dan Aktualitas Pancasila (Gramedia Pustaka Utama 2011) 42-46.

46 Mahkamah Konstitusi Republik Indonesia, Op.Cit 425. 
lainnya. ${ }^{47}$ Sejalan juga yang dikemukakan oleh Notonogoro yang menyatakan:

"Isi-arti sila Ketuhanan Yang Maha Esa, yang tidak terikat kepada bentuk Ketuhanan Yang Maha Esa yeng tertentu, akan tetapi tidak memperkosa dari inti dan istilah sila Ketuhanan Yang Maha Esa, dengan kata lain batasbatas daripada inti-isinya harus cukup luas untuk dapat menempatkan senua agama dan kepercayaan di dalamnya". 48

Hukum negara Indonesia pengayom dan pelindung bangsa Indonesia dan masyarakat Indonesia haruslah memiliki nilai dan sifat ketuhanan didalamnya, yang tidaklah memihak terhadap salah satu golongan tertentu, individu tertentu, agama tertentu, atau keegoisan dari individu dalam membuat, menerapkan dan menjalankan hukum di Indonesia. ${ }^{49}$ Apabila ditinjau dari sudut Ilmu Negara sejalan juga dengan teori yang dikaitkan dengan tujuan akhir manusia yaitu kebahagiaan hidup di akhirat, sehingga mempengaruhi pula dalam melaksanakan kehidupan di dunia. 50

Kemajemukan hukum Indonesia terlihat dari adanya suku-suku bangsa yang menghuni Indonesia yang diikat oleh organisasi yang dinamakan sebagai negara. Sila Kemanusiaan Yang Adil Dan Beradab berintikan kata manusia, yaitu manusia yang merupakan mahkluk individu dan mahkluk sosial yang memilki jiwa, akal, rasa, dan kehendak yang mencari sebuah kebahagiaan sempurna untuk tujuannya.51 Menurut Al-Sayyid Muhammad Ma'ruf al-Dawalibi dari Universitas Islam Internasional Paris, seperti dikutip Nurcholish Madjid.

“...yang paling menakjubkan dari semuanya tentang Konstitusi Madinah itu ialah bahwa dokumen itu memuat, untuk pertama kalinya dalam sejarah, prinsip-prinsip dan kaedah-kaedah kenegaraan dan nilai-nilai kemanusiaan yang sebelumnya tidak pernah dikenal umat manusia". ${ }^{52}$

Keberpihakan Islam terhadap HAM ini melalui Piagam Madinah dilanjutkan oleh Deklarasi Kairo (The Cairo Declaration of Human Rights in Islam) pada 5 Agustus 1990. Deklarasi ini dinyatakan oleh 45 negara anggota Organisasi Konferensi Islam (OKI), sebagai hasil Konferensi Islam ke-19 yang diadakan di Kairo, Mesir, pada 31 Juli-5 Agustus 1990. Pada intinya,

47 Kutipan Sekretariat Jenderal MPR-RI, Op.Cit 470-471. "Kemudian ada juga yang berkenaan dengan agama itu, mengenai apa negara berdasarkan Ketuhanan Yang Maha Esa dan menjamin, Pasal 29 Ayat (2), menjamin kemerdekaan untuk memeluk agamanya masing-masing. Ini juga pada prinsipnya tetap relevan meskipun kemudian kita perlu mengkaji lebih jauh, sejauh mana batas-batas kebebasan pemeluk beragama itu sendiri dalam kaitannya dengan fungsi negara sebagai satu institusi yang paling tidak itu mengatur kehidupan sosial kemasyarakatan. Kalau tidak misalnya sebagaimana yang sudah sering kita dengar tidak mencampuri urusan agama, mencampuri urusan ritual, ibadah, teologi agama. lihat Mahkamah Konstitusi Republik Indonesia, Op. Cit 373.

48 Notonegoro dalam Made Hendra Widjaya, Op.Cit 206.

49 Made Hendra Widjaya, Ibid 206-207. Lihat juga Ibnu Sina Candranegara, 'Fungsi Falsafah Negara dalam Konsep Penerapan Negara Hukum’ (2014) 11 Jurnal Cita Hukum 55,64.

50 Maleha Soemarsono, 'Negara Hukum Indonesia di Tinjau dari Sudut Teori Tujuan Negara' (2007) Tahun ke-37 Jurnal Hukum dan Pembangunan 295,301.

51 Plato mendefinisikan hukum sebagai suatu sistem aturan-aturan positif yang terorganisir atau terformulasi, mengikat pada keseluruhan individu dalam negara. Lihat Hayat, Op.Cit 389.

52 Nurcholish Madjid, dkk., Konstektualisasi Doktrin Islam dalam Sejarah (Yayasan Paramadina Jakarta 1994) 590. Mahkamah Konstitusi Republik Indonesia, Op.Cit 24-30. 
Deklarasi Kairo menyatakan penghapusan diskriminasi berbasis ras, warna kulit, bahasa, kepercayaan, jenis kelamin, agama, afiliasi politik, maupun status sosial dengan mendasarkan kepada Syariat Islam. 53

Dalam Piagam Madinah terdapat setidaknya dua ajaran pokok yakni semua pemeluk Islam adalah satu umat walaupun mereka berbeda suku bangsa. Hubungan antara komunitas muslim dengan komunitas nonmuslim didasarkan pada prinsip-prinsip berikut:

1. Berinteraksi secara baik dengan sesama tetangga;

2. Saling membantu dalam menghadapi musuh bersama;

3. Membela mereka yang teraniaya;

4. Saling menasehati;

5. Menghormati kebebasan beragama. Dalam hukum negara haruslah berisikan tentang nilai-nilai yang berisikan kemanusiaan yaitu nilai saling menghormati manusia satu sama lain, memberikan pengakuan terhadap manusia satu dengan lainnya, menganggap seluruh manusia adalah keluarga yang dilindungi, serta menciptakan keharmonisan antara manusia dalam melaksanakan kehidupan berbangsa dan bernegara. Di Abad Reformasi dan Pencerahan, pribadi insani dalam hubungannya dengan penguasa memperoleh tempat yang lebih sentral dalam pemikiran hukum. ${ }^{54}$ Filosof John Locke, misalnya, meletakkan dasar pengakuan hak fundamental manusia, yang tidak dapat dipindahkan kepada orang lain, dan harus dijamin oleh penguasa.

Sila Persatuan Indonesia, yang berintikan kata satu, menghendaki bangsa dan masyarakat Indonesia memiliki rasa, jiwa dan kehendak yang satu untuk mencapai tujuan dan citacita bangsa. Para founding father bangsa Indonesia memahami bahwa di dalam negara Indonesia terdapat berbagai macam ragam bangsa, suku, ras dan bahasa, sehingga para pendiri bangsa menghendaki nilai satu dari kesatuan di Indonesia di jalankan dan dilaksanakan dalam kehidupan bermasyarakat, berbangsa dan bernegara. Nilai dari kesatuan ini dapat diterapkan dengan mempertebal rasa toleransi, rasa gotong royong, dan rasa saling memiliki sebagai satu kesatuan keluarga. Selain dalam kehidupan sosial, nilai dan jiwa kesatuan ini juga hendaknya ada dalam pembentukan, pelaksanaan dan penerapan hukum di Indonesia, sehingga hukum dapat dijadikan sebagai alat untuk mempersatukan tujuan, nilai dan jiwa masyarakat Indonesia, agar tidak diterapkan secara berpihak dan berbedabeda.

Menurut Soekarno, Indonesia harus dibangun sebagai negara kekeluargaan. $\mathrm{Hal}$ ini jelas dinyatakan dalam pidatonya di hadapan Sidang Kedua BPUPK, pagi 15 Juli 1945.

"Buanglah sama sekali faham individualisme itu, janganlah dimasukkan dalam Undang-Undang

53 Safroedin Djafar, Mahkamah Konstitusi Republik Indonesia, Ibid 27.

54 Pemikiran Locke berpengaruh besar terhadap kemajuan di bidang kodifikasi HAM. Kodifikasi dimaksud antara lain adalah English Bill of Rights tahun 1689, The United States Declaration of Independence tahun 1776, dan France Declaration des droits de l'homme et du citoyen tahun 1789. Beberapa kodifikasi ini pada gilirannya dipergunakan sebagai contoh untuk pemastian HAM oleh banyak sistem hukum nasional. 
Dasar kita yang dinamakan 'rights of the citizens' sebagai yang dianjurkan oleh Republik Perancis itu adanya... Tuan-tuan yang terhormat! Kita menghendaki keadilan sosial. Buat apa Grondwet menuliskan bahwa manusia bukan saja mempunyai hak kemerdekaan suara, kemerdekaan memberikan hal suara, mengadakan persidangan dan berapat, jikalau misalnya tidak ada sosial rechtvaardigheid yang demikian itu? Buat apa kita membikin grondwet, apa guna grondwet itu kalau ia tak dapat mengisi perut orang yang hendak mati kelaparan. Grondwet yang berisi droit de'l homme et du citoyen itu, tidak bisa menghilangkan kelaparannya orang miskin yang hendak mati kelaparan. Maka oleh karena itu, jikalau kita betulbetul hendak mendasarkan negara kita kepada paham kekeluargaan, paham tolong menolong, paham gotog royong dan keadilan sosial, enyahkanlah tiaptiap pikiran, tiap-tiap paham individualisme dan liberalisme dari padanya". 55

Pendapat Soekarno didukung Soepomo (darinya kita mengenal negara kekeluargaan) yang juga berpendapat tidak perlu memasukkan pengaturan mengenai HAM dalam Undang-Undang Dasar.

"UUD yang kami rancangkan, berdasarkan atas paham kekeluargaan, tidak berdasar atas paham perseorangan, yang telah kita tolak. Pernyataan berkumpul dan berserikat di dalam UUD adalah sistematik dari paham perseorangan, oleh karena itu dengan menyatakan hak bersidang dan berserikat di dalam UUD kita akan menantang sistematik paham kekeluargaan". 56

Sila Kerakyatan Yang Dipimpin Oleh Hikmat Kebijaksanaan Dalam Permusyawaratan/Perwakilan yang berintikan rakyat yang artinya seluruh bangsa dan masyarakat Indonesia berasal dari rakyat dan tujuan serta cita-citannya untuk kepentingan seluruh rakyat di Indonesia. Sehingga hak dan kewajiban dari rakyat dapat tercipta secara seimbang, sehingga rakyat Indonesia membutuhkan seorang pemimpin yang berasal dari rakyat yang memiliki kebijaksanaan untuk memimpin bangsa dan masyarakat Indonesia agar terbentuknya keseimbangan hak dan kewajiban rakyat untuk bangsa dan negara Indonesia dengan menggunakan system demokrasi Pancasila yaitu musyawarah untuk mencapai mufakat.

Sila kelima Pancasila yang berbunyi "Keadilan Sosial Bagi Seluruh Rakyat Indonesia". Di dalam sila kelima Pancasila berintikan kata adil, yaitu adil yang memiliki sifat universal, atau adil yang sebenarnya yaitu adil yang tidak memihak, dan nilai adil yang ada dan dapat dirasakan oleh semua masyarakat dan bangsa Indonesia. Nilai dalam sila ini adalah tujuan dari bangsa Indonesia, yaitu menciptakan keadilan yang sama untuk seluruh bangsa dan masyarakat Indonesia, bukan merupakan keadilan yang dibedabedakan. Selain itu keadilan yang diharapkan adalah keadilan yang berisikan kedaulatan dari manusia, pengakuan, serta kebebasan yang mendasar untuk diberikan kepada masyarakat dan bangsa Indonesia.

55 Mahkamah Konstitusi Republik Indonesia, Op.Cit 28.

56 Mahkamah Konstitusi Republik Indonesia, Ibid 28. 


\section{PENUTUP}

Kemajemukan

masyarakat

Indonesia tercermin dalam praktik kehidupan. Sebagai negara hukum Pancasila, negara Indonesia coba meramu kemajemukan ke dalam Lima Sila yang terdapat dalam Pancasila. Karakteristik konsep negara hukum Pancasila terletak pada hukum negara yang didasari pada sila-sila yang ada di dalam Pancasila, yaitu Supremasi Hukum yang berlandaskan pada silasila Pancasila; negara berketuhanan, menjunjung tinggi nilai kemanusiaan, memiliki rasa persatuan, adanya kedaulatan rakyat dan adanya rasa keadilan. Negara hukum Pancasila dapat dikatakan sebagai visi bernegara dan untuk mewujudkan visi tersebut menggunakan misi yang dinamakan sebagai hukum negara.

Hukum negara sebetulnya mengarah pada hukum positif, sengaja digunakan oleh penulis untuk membuka wawasan yang berkenaan dengan keilmuan ilmu hukum. Konsep negara hukum Aristoteles walaupun masih dibilang sederhana, namun, dalam tataran normatif negara hukum Pancasila tidak jauh berbeda, dimana lima sila yang ada merupakan siklus yang akan saling berkaitan satu sama yang lainnya. Nilai ketuhanan akan membentuk nilai kemanusian, kemudian sebagai manusia majemuk akan memiliki nilai persatuan. Nilai persatuan diaplikasikan pada nilai kerakyatan yang menitikberatkan pada nilai-nilai sosial yang adil.

\section{DAFTAR BACAAN}

\section{Buku}

Arumanadi, Bambang dan Sunarto, Konsepsi Negara Hukum Menurut UUD 1945 (IKIP Semarang Press 1990).

Ashiddiqie, Jimly, Konstitusi dan Konstitusionalisme Indonesia (Konstitusi Press Jakarta 2005).

Ashiddiqie, Jimly, Pokok-Pokok Hukum Tata Negara Pasca Reformasi (Buana Ilmu Populer Jakarta 2007).

Azhary, Muhammad Tahir, Negara Hukum Suatu Studi tentang Prinsipprinsipnya Dilihat dari Segi Hukum Islam Implementasinya pada Periode Negara Madinah dan Masa Kini (Predana Media Jakarta 2003).

Azhary, Muhammad Tahir, Negara Hukum Indonesia (UI Press Jakarta 1995).

Azhary, Muhammad Tahir, Negara Hukum (Kencana Jakarta 2010).

Bahar, Safroedin dkk. Peny, Risalah Sidang Badan Penyelidik UsahaUsaha Persiapan Kemerdekaan Indonesia (BPUPKI)-Panitia Persiapan Kemerdekaan Indonesia (PPKI): 28 Mei 1945-22 Agustus 1945 (Sekretariat Negara Republik Indonesia Jakarta 1995).

Daman, Rozikin, Hukum Tata Negara (PT. Raja Grafindo Persada Jakarta 1993).

El. Muhtaj, Majda, Hak Asasi Manusia dalam Konstitusi Indonesia (Kencana Jakarta 2005).

Hadjon, Philipus M, Perlindungan Hukum Bagi Masyarakat di Indonesia (Bina Ilmu Surabaya 1987).

Hadjon, Philipus M, Kedaulatan Rakyat Negara Hukum dan Hak Asasi 
Manusia: Kumpulan Tulisan dalam Rangka 70 Tahun Sri Soemantri Mertosoewignjo (Media Pratama Jakarta 1996).

HR, Ridwan, Hukum Administrasi Negara (PT. Raja Grafindo Persada Jakarta 2006).

Huda, Ni'matul, Negara Hukum Demokrasi dan Judicial Review (UII Press Yogyakarta 2005).

Huda, Ni'matul, Hukum Tata Negara Indonesia, (PT. Raja Grafindo Persada Jakarta 2006).

Kusnardi, Moh. dan Ibrahim, Harmaily, Hukum Tata Negara Indonesia (Sinar Bakti Jakarta 1987).

Latif, Yudi, Negara Paripurna: Historisitas, Rasionalitas, dan Aktualitas Pancasila (Gramedia Pustaka Utama Jakarta 2011).

Madjid, Nurcholish dkk., Konstektualisasi Doktrin Islam dalam Sejarah (Yayasan Paramadina Jakarta 1994).

Mahfud MD, Moh, Konstitusi dan Hukum dalam Kontroversi Isu (PT Rajagrafindo Persada Jakarta 2009).

Mahkamah Konstitusi Republik Indonesia, Naskah Komprehensip Perubahan Undang-Undang Dasar Negara Republik Indonesia Tahun 1945:Latarbelakang, Proses dan Hasil Pembahasan 1999-2002 Buku VIII Warga Negara dan Penduduk, Hak Asasi Manusia dan Agama (Edisi Revisi, Sekertariat Jenderal dan Kepaniteraan Mahkamah Konstitusi Jakarta 2010).

Majelis Permusyawaratan Rakyat Republik Indonesia, Panduan Pemasyarakatan Undang-Undang Dasar Republik Indonesia Tahun 1945 (Sesuai dengan Urutan Bab,
Pasal, dan ayat) (Sekertaris Jendral MPR RI Jakarta 2010)

Muslehuddin, Muhammad, Filsafat Hukum Islam dan Pemikiran Orientalis, (terj. Yudian Wahyudi Asmin, Tiara Wacana Yogyakarta 1991).

Nasution, Irfan. dan Agustinus, Roni (Peny.), Restorasi Pancasila; Mendamaikan Politik Identitas dan Modernitas (FISIP UI Jakarta 2006).

Rahardjo, Satjipto, Negara Hukum yang Membahagiakan Rakyatnya (Genta Publishing Yogyakarta 2009).

Rahardjo, Satjipto, Pendidikan Hukum Sebagai Pendidikan Manusia, (Genta Publishing, Yogyakarta 2009).

Sarip, 2018, Hukum Tata Negara Materil Elsi Pro Cirebon.

Suhino, 1986, Ilmu Negara, Liberty Yogyakarta.

Thaib, Dahlan, Kedaulatan Rakyat Negara Hukum dan Hak Asasi Manusia: Kumpulan Tulisan dalam Rangka 70 Tahun Sri Soemantri Mertosoewignjo (Media Pratama Jakarta 1996).

Tutik, Titik Triwulan, Pokok-Pokok Hukum Tata Negara (Prestasi Indonesia Jakarta 2006).

\section{Jurnal, Makalah, Website}

Azhari, Aidul Fitriciada, Negara Hukum Indonesia: Dekolonisasi dan Rekonstruksi Tradisi' (2012) 19 Jurnal Hukum Ius Quia Iustum.

Budiman, Manneke, 'Jatidiri Budaya Dalam Masyarakat Multikultural' (2003) Makalah Seminar Pendidikan Multikultural dan Revitalisasi Hukum Adat dalam Perspektif Budaya, Departemen Kebudayaan 
dan Pariwisata, Bogor 18-20 Desember 2003.

Candranegara, Ibnu Sina, 'Fungsi Falsafah Negara dalam Konsep Penerapan Negara Hukum' (2014) 11 Jurnal Cita Hukum.

Dayanto, 'Rekontruksi Paradigma Pembangunan Negara Hukum Indonesia Berbasis Pancasila' (2013) 13 Jurnal Media Hukum.

Djafar, Wahyu, 'Menegaskan Kembali Komitmen Negara Hukum: Sebuah Catatan Atas Kecenderungan Defisit Negara Hukum di Indonesia' (2010) 7 Jurnal Konstitusi.

Hayat, 'Keadilan Sebagai Prinsip Negara Hukum: Tinjuan Teoritis dalam Konsep Demokrasi' (2015) 2 Jurnal Ilmu Hukum PADJAJARAN.

Kamus online Bahasa Indonesia https://www.kbbi.web.id/majemuk . diakses 2 Februari 2018.

Lay, Cornelis, 'Nasionalisme dan Negara Bangsa' (2006) 10 Jurnal Ilmu Sosial dan Ilmu Politik.

Mutaqim Muhammad dan Miftah Muhammad, Tantangan NegaraBangsa (Nation-Staate) dalam Menghadapi Fundamentalisme Islam' (2015) 9 Jurnal ADDIN.

Ngoro, Adrianus M, 'Makna Negara Hukum dalam Persefektif Politik Hukum: Telaah Yuridis Materil dan Formil' (2017) 2 Jurnal Hukum Sehasen.

Nurdin, 'Konsep Kedaulatan dan Keadilan dalam Konsep Islam dan Barat' (2011) XIII Jurnal Media Syariah.

Republik Indonesia Undang-Undang Dasar 1945.

Riyanto, Sigit, 'Kedaulatan Negara dalam Kerangka Hukum Internasional Kontemporer' (2012) 1 Jurnal Yustisia 1.
Riyanto, Sigit, Re-interprestasi Kedaulatan Negara dalam Hukum Internasional, dalam Pidato Pengukuhan Jabatan Guru Besar Fakultas Hukum Universitas Gajah Mada Yogyakarta, tanggal 26 Juni 2014.

Sayuti, 'Konsep Rechtsstaat dalam Negara Hukum Indonesia: Kajian Terhadap Pendapat Azhari' (2017) 4 Jurnal Kajian Islam dan Kemasyarakatan NALAR FIQH.

Soemarsono, Maleha, 'Negara Hukum Indonesia di Tinjau dari Sudut Teori Tujuan Negara' (2007) Tahun ke-37 Jurnal Hukum dan Pembangunan.

Sugiyarto, 'Tantangan Terhadap Eksistensi Negara Bangsa Indonesia dalam Pemaknaan Kembali Nasionalisme', http:/ / eprints.undip.ac.id/57965/ 1/Tantangan_terhadap_Eksistensi_ Negara_Bangsa_Indonesia_dan_Pe maknaan_Kembali_Nasionalisme.p df diakses 20 Februari 2018.

Syahbana, Erwin, 'Sistem Hukum Perkawinan pada Negara Hukum Berdasarkan Pancasila' (2012), 2 Jurnal Ilmu Hukum.

Wijaya, Made Hendra, 'Karakteristik Konsep Negara Hukum Pancasila' (2015) 5 Jurnal Advokasi. 
